\title{
ECOLOGY AND DISTRIBUTION OF TWO SYMPATRIC, CLOSELY RELATED SPONGE SPECIES, HALICHONDRIA PANICEA (PALLAS, 1766) AND H. BOWERBANKI BURTON, 1930 (PORIFERA, DEMOSPONGIAE), WITH REMARKS ON THEIR SPECIATION
}

by

\author{
A. D. VETHAAK, R. J. A. CRONIE \& R. W. M. VAN SOEST \\ Institute of Taxonomic Zoology, University of Amsterdam, \\ P.O. Box 20125, 1000 HC Amsterdam, The Netherlands
}

\begin{abstract}
North Atlantic coastal waters harbour two closely related sympatric sponges belonging to the genus Halichondria, viz. $H$. panicea and $H$. bowerbanki. From the study of their littoral and sublittoral microdistribution and ecology in the Oosterschelde area $(=$ Eastern Scheldt, S.W. part of The Netherlands) it is concluded that both occupy largely similar niches, although it was found that $H$. panicea is better equipped to endure exposure to air since it occurs up to a higher intertidal level than $H$. bowerbanki, while the Iatter is better equipped to withstand siltation. Other environmental factors as depth, light, current velocity and salinity affect the distribution and behaviour of both species similarly. From these observations it can be inferred, that speciation from a parent species cannot have been sympatrically through ecological segregation of individuals. The possibilities of geographical isolation of populations of a parent species on both sides of the Atlantic Ocean during past glacial periods resulting in an originally American species ( $H$. bowerbanki) and an originally European species (H. panicea), are discussed.
\end{abstract}

\section{RESUME}

Les eaux côtières de l'Atlantique Nord hébergent deux espèces sympatriques fort apparentées de Spongiaires appartenant au genre Halichondria, à savoir $H$. panicea et $H$. bowerbanki. L'étude de leur microdistribution et de leur écologie dans le littoral et le sublittoral de la zone de l'Oosterschelde (- l'Escaut oriental, partie S.O. des Pays-Bas) permet de conclure que les deux occupent des niches en général similaires; on a cependant trouvé que $H$. panicea est mieux adaptée à l'exposition à l'air, puisqu'elle peut être présente jusqu'à un niveau intercotidal supérieur à celui atteint par $H$. bowerbanki, tandis que cette dernière espèce est mieux préparée pour résister à l'envasement. D'autres facteurs du milieu, comme la profondeur, la lumière, la vitesse du courant, la salinité, affectent de manière similaire la distribution et le comportement des deux espèces. On peut déduire de ces observations que, dans ce cas, la spéciation a partir d'une espèce parentale n'a pas pu être sympatrique, par ségrégation écologique des individus. On discute des possibilités d'isolation géographique de populations d'une espèce parentale des deux côtés de l'Atlantique au cours des périodes glaciaires, ayant comme résultat une espèce d'origine américaine $(H$. bowerbanki' et une autre d'origine européenne (H. panicea).

\section{INTRODUCTION}

The sympatric occurrence of two or more closely related species has inspired the development of speciation theories in which ecological niche differentiation plays a major role (e.g. Ross, 1974: 101-106). Such a presumed mode of speciation does not necessitate geographical isolation of populations (through vicariance or dispersal), which is normally considered the most parsimonious way of speciation. Sympatric speciation is made quite feasible in certain parasitic insects, but convincing unequivocal examples in other animal groups or habitats are rare. In the marine environment suggestions of sympatric speciation have been made by Sara $(1956,1957)$ when trying to explain the sympatric occurrence of the calcareous sponges Leucosolenia complicata (Montagu, 1818), L. variabilis Haeckel, 1870 and $L$. botryoides (Ellis \& Solander, 1786) in western Europe, and by McGowan (1963) when trying to explain the sympatric occurrence of the pelagic molluscs Limacina belicina (Phipps, 1774) varieties $A$ and $B$, in the North Pacific.

A strong indication for a possible sympatric speciation is the niche differentiation such a group of closely related species should exhibit. This indication is, however, still not conclusive because niche differentiation may just as well have occurred after the speciation event instead of being the cause of it. At any rate, without such a clear niche differentiation a theory of sympatric speciation (difficult enough to explain in itself) would be unwarranted.

The alternative theory, speciation through geographical isolation, has been used to explain marine speciation events, but not very widely 
because it involves a rather intimate knowledge of past geological and climatological events and data on the dispersal capabilities of the species concerned. In tropical parts of the oceans these events are known to a modest degree: we can explain many vicariant distributions of closely related benthic marine taxa by the former existence of the Tethys Sea and its subsequent disruption because of the openings of the Atlantic Ocean (e.g. Ekman, 1953; Briggs, 1974; for sponges: Wiedenmayer, 1977). In the pelagic environment such vicariance theories have been formulated by Brinton (1962), Van Soest (1975), and Pierrot \& Van der Spoel (1979). In most individual cases, however, there is always a lack of sufficient data on the past distribution of the species involved and the geological events that should have led to the segregation of populations of the ancestral species.

In the following we will try to reconstruct the evolutionary scenario of two closely related sponge species, viz. Halichondria panicea (Pallas, 1766) and $H$. bowerbanki Burton, 1930, which occur sympatrically in most of their geographic ranges. Because literature data suggest a niche differentiation in these species it will be attempted to show at length, that the ecology of both species precludes the assumption of sympatric speciation. Subsequently an alternative way of speciation will be discussed. The predictive value of our results is unknown, although several similar cases of closely related, sympatric, marine benthic species pairs in other animal groups are known to exist.

\section{ACKNOWLEDGEMENTS}

The authors are very much indebted to $\mathrm{Mr}$. Jan Vermeulen for his excellent assistance in the field. Furthermore, we are grateful to Mr. J. Zaagman for retouching the photographic illustrations and for assembling the plates; Mr. H. Mittelberg made the frame box apparatus. Miss S. M. Stone (British Museum (Natural History)), Dr. P. R. Bergquist (Auckland, New Zealand) and Dr. E. Rasmussen (Copenhagen) are thanked for putting material at our disposal.

\section{MATERIALS AND METHODS}

The fieldwork part of this study was carried out by making regular visits to 17 localities in the Oosterschelde (Eastern Scheldt) area during a three-year period from November 1977 till December 1980.
Sampling of the sponge populations was performed by hand, hand-operated grabs, snorkeling, SCUBA diving and dredging.

The following preserved material from the collections of the Zoölogisch Museum, University of Amsterdam (ZMA), the Rijksmuseum van Natuurlijke Historie at Leiden (RMNH), the British Museum (Natural History), London (BMNH) and the Zoologisk Museum, University of Copenhagen (ZMUC) has been used in the present study:

\section{Halichondria panicea:}

ZMA (The Netherlands): Por. 2985 through 3035; 3063; $3069 ; 3070 ; 3077 ; 3079 ; 3086 ; 3093 ; 3094 ; 3101$; 3103 ; 3115 ; 3123 ; 3128 ; 3131 through 3135 ; 3152; $3157 ; 3161$ through $3169 ; 3179 ; 3182$ through 3185 ; 3220 ; 3224; 3226; 3229; 3234; 3246; 3466; 3471; $3973 ; 4083 ; 4105$ through $4107 ; 4109 ; 4111$ through 4115; 4162; 4175; 4202; 4207; 4209; 4216; 4221; $4223 ; 4227 ; 4329 ; 4330 ; 4332 ; 4336 ; 4449$ through $4451 ; 4478 ; 4574 ; 4575$.

ZMA (Ireland): Por. 4426; 4689; 4690.

ZMA (New Zealand; donated by P. Bergquist, Auckland University): Por. 4553.

ZMA (France): Por. 2485; 2496; 2498.

RMNH (The Netherlands): Nos. 423 through 432; 1075 through $1081 ; 1082$ through $1085 ; 1086 ; 1087$ through 1091; 1156 through $1159 ; 1162 ; 1164$; 1181 through $1183 ; 1191 ; 1193 ; 1207 ; 1209$; 1210 through $1213 ; 1218 ; 1219 ; 1222 ; 1224$; $1230 ; 1231 ; 1255 ; 1263$ through $1265 ; 1275$; 1280; 22 samples, unnumbered.

BMNH material, labeled Halichondria panicea: Sealark Exped., Indian Ocean; Lambert Bay, S. Africa; Pt. Noloth, S. Africa (1938.3.26.72); Manihine Exped., Gulf of Aqaba; Challenger Exped., Kerguelen, Indian Ocean (1887.6.2.216); Challenger Exped., Japan; Mergui Archipel, Birma; Cape Adare, Antarctica; Japanese Sea; Greenland; Esquimault Harbour, Vancouver, W. Canada; S. Sachalin, U.S.S.R. (1931.6.10.10); Inverness Woodcock's Landing, Estuary of the Sheena River, British Columbia, W. Canada (1890.9.2.1); Swedish Antarctic Exped., Falkland Isls. (1933.3.17.19; no sponge).

ZMUC Atlantide Exped., Sta. $146\left(9^{\circ} 24^{\prime} \mathrm{N} 14^{\circ} 45^{\prime} \mathrm{W}\right)$, s0-51 m.

Halichondria bowerbanki:

ZMA (The Netherlands): Por. 2681; 3138; 3146 through $3148 ; 3472 ; 4087$ through $4090 ; 4099 ; 4101 ; 4103$; 4116 through $4118 ; 4122$ through $4125 ; 4132 ; 4133$; $4199 ; 4203 ; 4219 ; 4220 ; 4224 ; 4328 ; 4331 ; 4334$; $4337 ; 4472 ; 4574 ; 4575$.

ZMA (Ireland): Por. 4297; 4421; 4547.

ZMA (France, as $H$. coalita): Por. 2490 through 2495; 2499.

BMNH: Plymouth; Naples (Italy). BMNH-material labeled "Halichondria lacunosa": Port Chevalier Reef, New Zealand (1938.8.24.12). BMNH-material labeled "Halichondria caduca": Challenger Exped., S.W. Patagonia. 
Reproductive periods of the sponges were determined during the years 1978, 1979 and 1980, by dissection and subsequent inspection under a stereomicroscope, of bimonthly collected samples (each from several sublittoral localities) for the presence of large eggs and embryos.

Explantation of sponges was accomplished by using as a starting point the method described by Simpson (1963). Sponge pieces of approximately

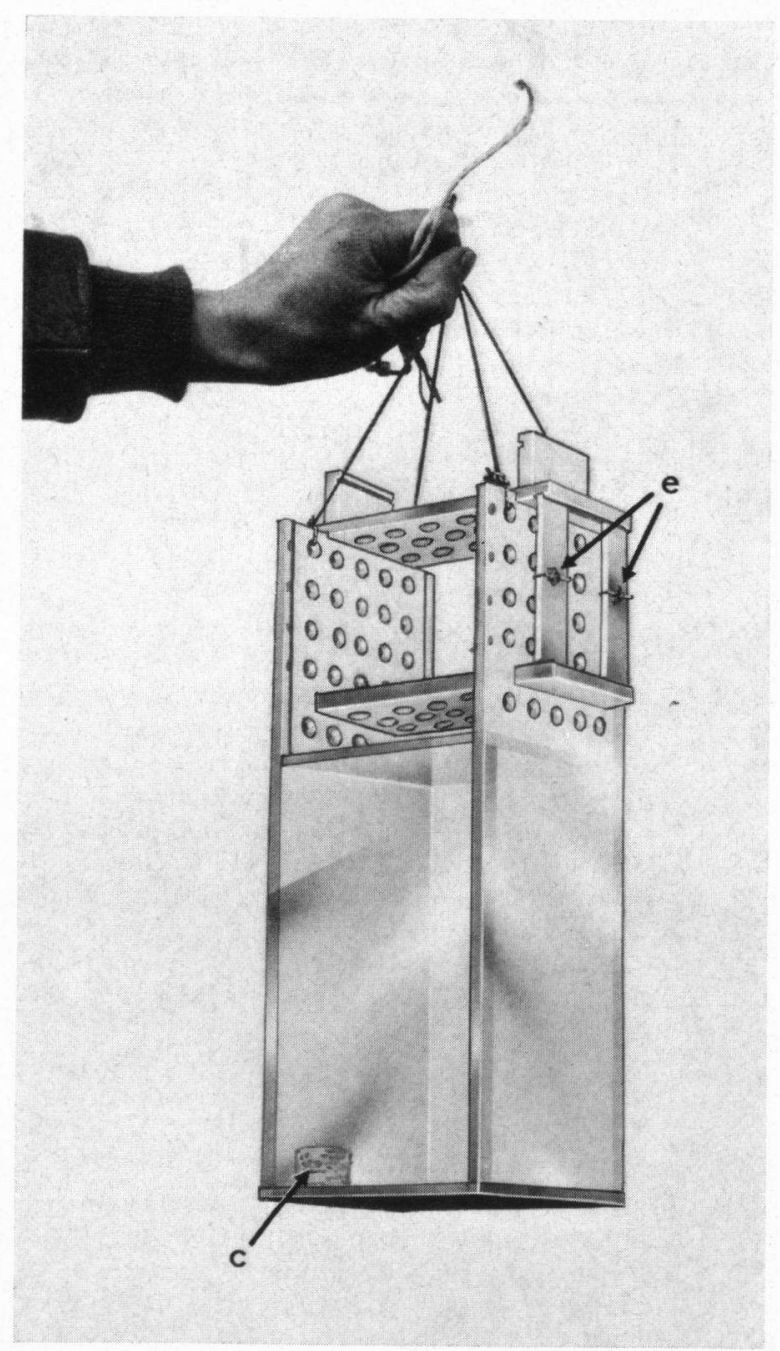

Fig. 1. Experimental set-up showing frame boxwith explants. The apparatus is made of plexiglass and consists of a box closed with a cork (c) and a perforated holder. Plexiglass plates $(8 \times 2 \mathrm{~cm})$ with explants (e) can be fixed in the holder in different positions. The weight of the frame box can be regulated by filling the box with water or sand (normal position, attachment to surface) or by filling it with air (upside-down position, attachment to bottom).
$0.5 \mathrm{~cm}^{2}$ were cut from the marginal basal zone of specimens (all collected in locality 5, fig. 2), tied with nylon thread on PVC slides $(8 \times 2 \mathrm{~cm})$ and fixed in vertical position on a specially designed frame box (see fig. 1). This procedure was executed under water. The frame box with explants was hung in the sublittoral at a pontoon under partly illuminated conditions (locality 5). After two weeks 4-6 successful, genetically and phenotypically identical explants (each series raised from one specimen) were selected and used for growth and transplantation experiments. Growth rates were determined by measuring the increase in diameter of the outgrowth regions (or the length if the outgrowth proved to be not circular) and expressed in $\mathrm{mm} /$ day.

\section{SHORT DESCRIPTION OF THE STUDY AREA}

The study area comprises the Oosterschelde sea-arm and small brackish inland waters which are situated in the southern part of an extensive estuarine region (Delta area), located in the southwestern part of The Netherlands (see fig. 2). The Oosterschelde contains very clear water, well mixed vertically, of which during each tide only $4 \%$ of the total volume is renewed. In the main gullies with a maximum depth of about $40 \mathrm{~m}$, but in landinward direction less deep, maximum current velocities during a tidal cycle are usually between 1.0 and $1.9 \mathrm{~m} / \mathrm{sec}$ (Anonymous, 1977). Sediment deposits within the Oosterschelde vary from mud to sand and cover the main part of the bottom. Natural rocks are absent, but artificial rocky areas have been created along the shores. During the period of 1978 to 1980 chlorinities in the Oosterschelde fluctuated between 13.8 and $18.0^{\circ} \%$ and water temperatures ranged between -1.5 and $21^{\circ} \mathrm{C}$ (based on daily or every other day measurements (Van Boven, 1981)). Detailed data of water temperatures in successive years are given in fig. 3 .

The salinity regimes of the brackish canals and creeks and pools, abundantly present behind the dikes of the Oosterschelde, vary greatly and their water temperatures show a slightly larger amplitude than those of the sea-arm.

\section{MORPHOLOGICAL DESCRIPTIONS OF THE SPECIES}

\section{Diagnosis of Halichondria panicea (Pallas, 1766)}

Shape: The shape of the individuals shows a large variation. Despite the occurrence of many intermediate forms, the following types may be recognized:

- P1: Incrustations without vertical outgrowths or with low tubules and/or slender branches (Pl. I 1, Pl. II 4). 


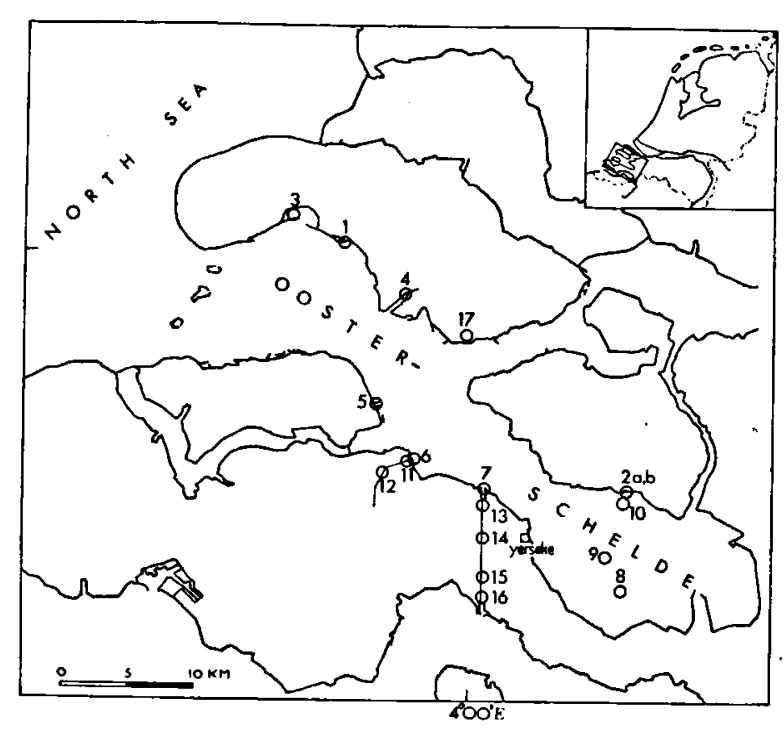

Fig. 2. The Oosterschelde area with sampled localities: $1=$ Schelphoek, harbour; $2 \mathrm{a}=$ Stryenham, pier near coast light; $2 \mathrm{~b}=$ Stryenham, silt plain; $3=$ Flauwers, dike, east of coast light; $4=$ Zierikzee, harbour; $5=$ Kats, harbour; $6=$ Sas van Goes, seaside sluices; $7=$ Wemeldinge, seaside sluices; 8 = Mosselkreek; $9=$ Lodijkse Gat; $10=$ Stryenham, stream gully near pier; $11=$ Canal Sas van Goes, sluices; 12 = Canal Sas van Goes, Wilhelminadorp; $13=$ Canal through Zuid Beveland, Wemeldinge, sluices; $14=$ Canal through Zuid Beveland, Postbrug; $15=$ Canal through Zuid Beveland, bridge; 16 = Canal through Zuid Beveland, Hansweert, sluices; $17=$ Brackish lagoon "Inlaag 1953 near Ouwerkerk".

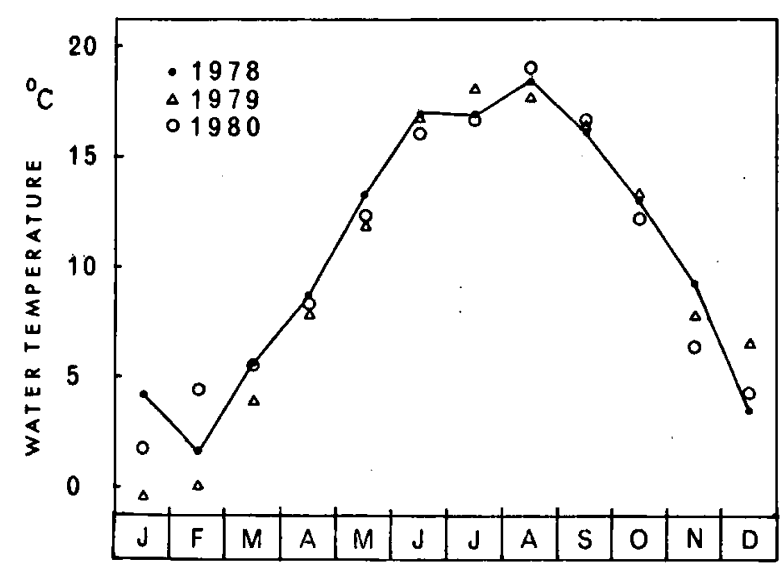

Fig. 3. Water temperatures of the Oosterschelde measured at Yerseke based on daily or every other day measurements at high tide, averaged per month (data derived from Delta Institute for Hydrobiological Research, see Van Boven, 1981).
- P2: A massive base with many elaborate oscular tubes ("chimneys"), often irregularly placed (PI. I 2).

- P3: A mass of long, rounded osculiferous branches, interconnected and anastomosing (PI. I 5).

- P4: A massive base with parallel osculiferous branches, oblique to one side, often anastomosing to form palmate structures or ridges (Pl. I 3, 4; Pl. II 1).

- P5: Compact irregular masses with or without thick flattened processes, which are closely adhering to the colony base (Pl. II 2, 5).

- P6: Apparently free-living, rounded masses without vertical outgrowths which assume their form by rolling on the seabed (these specimens were collected in the open North Sea near Dogger Bank, $-30 \mathrm{~m}$ ) (PI. II 3).

Size: Largest specimen observed is about $60 \mathrm{~cm}$ across and about $25 \mathrm{~cm}$ in height (growth form P3), but much smaller specimens are the rule.

Live colour: Lightly orange-yellow with or without various shades of green (very likely due to the presence of symbiontic algae), sometimes a beautiful orange-green. Winter specimens are occasionally light-yellow or whitish.

Consistency: Compressible, easily torn; specimens often emit an unmistakable, disagreeable, carbid-like odour.

Surface: Smooth or somewhat wrinkled. Oscules, both on the summits or flush, $0.5-7.0 \mathrm{~mm}$ in diameter. The dermal membrane is skinlike (up to $0.6 \mathrm{~mm}$ thick) and easily peeled off.

Skeleton: The spicules are arranged quite confused or more rarely somewhat regular. The arrangement of the spicules in the dermis is tangential and has the characteristic pattern figured by Hartman (1958: fig. 9).

Spicules: Long, thin oxea; occasionally stylote modifications are found. Size of dermal oxea is significantly smaller than that of the endosome (cf. table I).

Time of reproduction: Large oocytes and embryos were found in specimens from mid-May until mid-August. 
TABLE I

Measurements (in $\mu \mathrm{m}$ ) of dermal and endosomal oxea of Halicbondria panicea. All specimens collected during August-September at different localities (based on $\mathbf{4 0}$ oxea per specimen).

\begin{tabular}{lcccc}
\hline & \multicolumn{2}{c}{ Dermis } & \multicolumn{2}{c}{ Endosome } \\
Locality & length & width & length & width \\
\hline $\begin{array}{l}\text { Zierikzee, } \\
\text { sublittoral }\end{array}$ & $200-269-333$ & $2.7-6.2-11.4$ & $238-311-380$ & $3.4-7.9-10.6$ \\
$\begin{array}{l}\text { Mosselkreek, } \\
\text { sublittoral }\end{array}$ & $190-245-346$ & $2.4-4.7-7.2$ & $232-290-380$ & $2.8-6.7-9.5$ \\
$\begin{array}{l}\text { Harbour of Kats, } \\
\text { sublittoral }\end{array}$ & $205-263-380$ & $2.4-6.7-12.0$ & $171-302-418$ & $3.8-7.6-13.3$ \\
$\begin{array}{l}\text { Sas van Goes, } \\
\text { non-tidal }\end{array}$ & $190-307-475$ & $3.8-7.2-13.3$ & $185-340-482$ & $3.8-7.7-13.6$ \\
$\begin{array}{l}\text { Stryenham, } \\
\text { littoral }\end{array}$ & $228-327-456$ & $2.4-7.4-12.4$ & $238-351-447$ & $2.8-7.6-13.3$ \\
\hline
\end{tabular}

\section{Diagnosis of Halichondria bowerbanki Burton, 1930}

Shape: The variability in shape is at least as large as in the previous species. Despite the occurrence of many intermediate forms we recognized the following types:

- B1: Incrustations without vertical outgrowths or with low tubules and/or slender branches; the branches are often lamellate (Pl. III 1, 3).

- B2: Bushlike specimens, consisting of long branches, which are irregularly branching again and are often lamellate at their summits; in other specimens the branches are intimately anastomosed to form a clump (B2*) (PI. III 2, 6).

- B3: A massive base from which arise vertical, more or less rounded branches, which are irregularly branching again and partly anastomosing; in other specimens the branches are oblique to one side and anastomosed (B3*) (Pl. III 4, Pl. IV 3).

- B4: A massive base from which arise irregular lamellate processes (lamellate ridges). Sometimes colonies consist of cushions of lamellate processes. More rarely, the processes are in the form of chimneys, resembling those of $H$. panicea (PI. IV 2 ). In other specimens the processes are arranged in one plane and anastomosing (B4*).

- B5: Compact, irregular masses with or without flattened outgrowths (Pl. III 5, Pl. IV 1).

Size: Specimens may grow to about $25 \mathrm{~cm}$ across and about $12 \mathrm{~cm}$ in height, but are usually much smaller.

Live colour: Beige or dull brownish grey. Specimens with reproductive elements are characteristically yellow orange. During the winter specimens become lighter in colour, being light grey yellow or whitish. Greenish shades are only rarely found.

Consistency: Compressible, easily torn, but slightly more elastic than $H$. paniced.

Surface: Uneven, frequently covered in silt or other debris. In many specimens, especially during wintertime, tracts of spicules protrude the surface slightly. Occasional oscules present on surface and branches but normally inconspicuous. Oscule sizes vary from $\mathbf{1} .0-2.0 \mathrm{~mm}$ in diameter. Dermal membrane much thinner than that of $H$. panicea.

Skeleton: As $H$. panicea, but the spicules in the dermis are more regularly arranged into tracts leaving open spaces, as figured by Hartman (1958, fig. 10).

Spicules: Similar to those of $H$. panicea. Oxea sizes of dermis similar or larger than those of the endosome (cf. table II).

Time of reproduction: Large oocytes and embryos were found in specimens from early August until mid-October.

Taxonomic separation of the two species rests primarily on the arrangement of the spicules in the dermal membrane. This agrees with obser- 
TABLE II

Measurements (in $\mu \mathrm{m}$ ) of dermal and endosomal oxea of Halichondria bowerbanki.
All specimens collected during August-September at different localities (based on 40 oxea per specimen).

\begin{tabular}{|c|c|c|c|c|}
\hline \multirow[b]{2}{*}{ Locality } & \multicolumn{2}{|c|}{ Dermis } & \multicolumn{2}{|c|}{ Endosome } \\
\hline & length & width & length & width \\
\hline $\begin{array}{l}\text { Zierikzee } \\
\text { sublittoral }\end{array}$ & $247-357-570$ & $7.6-10.0-13.3$ & $133-299-430$ & $2.6-7.8-13.3$ \\
\hline $\begin{array}{l}\text { Mosselkreek, } \\
\text { sublittoral }\end{array}$ & $238-321-475$ & $7.6-9.9-13.3$ & $133-286-390$ & $2.6-6.7-12.0$ \\
\hline $\begin{array}{l}\text { Inlaag } 1953 \text { near Ouwerkerk, } \\
\text { non-tidal }\end{array}$ & $228-298-361$ & $3.6-7.2-13.8$ & $133-284-380$ & $2.3-7.1-15.2$ \\
\hline $\begin{array}{l}\text { Stryenham, } \\
\text { littoral }\end{array}$ & $143-319-437$ & $4.6-7.5-11.4$ & $152-320-437$ & $3.8-8.7-13.3$ \\
\hline $\begin{array}{l}\text { Sas van Goes, } \\
\text { non-tidal }\end{array}$ & $200-341-456$ & $7.6-10.1-11.8$ & $152-318-400$ & $2.3-6.6-13.3$ \\
\hline
\end{tabular}

vations made by Hartman (1958) and GraatKleeton (1965). Before a definite identification can be made, it is however necessary to study various parts of the dermis. Another taxonomic difference between the species is the size discrepancy in spicules from dermis and endosome in $H$. panicea (which points towards close relationship with the genus Topsentia). Specimens from eastern North America, England and France studied by Hartman (1958) and a specimen from Denmark studied by Brøndsted (1929) proved to exhibit similar differences. Next to this, the species show a consistent difference in the time of reproductive activity as will be demonstrated below.

In other features the two species overlap in a larger or lesser degree. This is also evident with respect to the growth form, although both species have different characteristic growth forms. "Chimney"-like outgrowths are regularly found in $H$. panicea only, and the bushlike form (B2) and lamellate processes are common in $H$. bowerbanki only.

Another North Atlantic Halichondria species is $H$. topsenti De Laubenfels, 1936 ( = H. reticulatus sensu Van Soest \& Weinberg, 1980), which is similar in appearance to $H$. panicea but may be readily recognized on account of its woodlike consistency and strongly developed, dense ectosomal crust (known from the South coasts of the British Isles and Brittany).

\section{SPECIES-HABITAT RELATIONSHIPS IN THE OOSTERSCHELDE AREA}

In order to detect possible different ecological preferences of the species, the localities studied in the S.W. parts of The Netherlands were divided into three general zones and a total of six habitats based on physical characteristics (tidal amplitude, depth, water movement, salinity, slope, type of hard substrate, and the nature and amount of sediment). High hydrodynamism corresponds to average (alternating tidal) current velocities of 0.3-0.8 m/sec (Anonymous, 1977), and low hydrodynamism means average current velocities much lower than $0.3 \mathrm{~m} / \mathrm{sec}$. Zero hydrodynamism is found in the absence of tidal movements or other significant water currents. Chlorinities of the inland waters are classified according to the Venice system (Anonymous, 1959): polyhaline is 16.5$10 \% \mathrm{Cl}^{-}$and mesohaline is $10-3 \% \mathrm{on}_{\mathrm{Cl}}$. Chlorinity data over the period 1968-1975 are derived from De Munck et al. (1978) and are in agreement with incidental measurements taken by us in 1978 and 1980. The localities sampled in each of the habitats are plotted in fig. 2.

\section{MICRODISTRIBUTION OF THE SPECIES}

The littoral environment

Habitat 1 (localities 1, 2a): Tidal amplitude about 3-3.5 m; low to high hydrodynamism; hard substrate comprises masses of loose-lying stones, barren or covered with a thin silt film. 
Considerable niche differentiation among the two species is apparent. Whereas $H$. panicea extends into the lower mid-littoral, occasionally even into the mid-littoral, the occurrence of $H$. bowerbanki is entirely restricted to the lower littoral, up to about mean low neaps. $H$. panicea predominates, both in its upper vertical range and in the lower intertidal parts. On occasional spots, however, $H$. bowerbanki may be equally common as $H$. panicea. Both species were encountered on shaded sides of stones but also on top sides fully exposed to light conditions (for seasonal variation of $H$. bowerbanki in this respect, see later section). Next to stones both species frequently used tunicates (mainly the introduced Styela clava) and molluscs as a substrate. Individuals remained often undersized in this habitat, notably $H$. bowerbanki.

Habitat 2 (locality 2b): Tidal amplitude $3.5 \mathrm{~m}$; low hydrodynamism; loose-lying stones covered with considerable amounts of silt (almost closed layer).

In this intertidal silt plain $H$. bowerbanki largely predominates. The species occurs on siltcovered stones, represented by silt-covered, small individuals. Specimens of $H$. panicea are rare, undersized and only found on occasional siltfree spots in the area, such as overhanging surfaces of large stones. Vertical ranges of the species are in accordance with the one described in the previous habitat.

\section{The sublittoral environment}

Habitat 3 (localities 3, 4, 5, 6 and 7): Depth 0-5 m; low hydrodynamism; stony banks, looselying stones on the bottom, piles, pontoons, sluice walls and gates; horizontal and sloping surfaces covered with much silt (closed layer).

In the shallow sublittoral of the sheltered harbours $H$. panicea is in most places more common than $H$. bowerbanki. Microdistributional patterns revealed, however, no significant differences in other respects. The species occurred in dense populations on silt-free overhangs and vertical surfaces (piles, sluice walls and gates, and pontoons), represented mostly by luxuriously growing in- dividuals. No specimens were observed growing on the heavy silt-covered banks and bottom. Although both species were often found exposed to full illumination, population densities were clearly higher on the more shaded or totally dark spots. We were fortunate in being enabled to study the populations on a drained sluice gate during its period of repair (locality 4). For years the inside part of the gate had remained in a quite shaded position. With the exception of a small lower littoral zone of the gate which was occupied by $H$. panicea only, the sublittoral parts were almost completely covered with mixed continuous populations of both species. They frequently partly overgrew each other and most of the tunicates and molluscs present. In this case, we could not detect evidence that one species was overgrowing the other more often than the reverse. Also no distinct change in biomass of the sponges on the sluice gate with increasing depth (down to $-4.5 \mathrm{~m}$ ) was apparent: the mean biomass of $H$. panicea was $19 \mathrm{dm}^{3} / \mathrm{m}^{2}$ and of H. bowerbanki $8 \mathrm{dm}^{3} / \mathrm{m}^{2}$.

Habitat 4 (localities 8, 9 and 10): Depth 0-20 m; high hydrodynamism; pavements of stones and boulders, peat (locality 10), oyster- and musselbeds, peat and eroded clay ridges (localities 8 and 9); hard substrate barren or covered with sand.

$H$. panicea is extremely common in the stream gullies, occurring in large sizes, abounding on all suitable substrates. $H$. bowerbanki is less common but can be locally encountered in niches very similar to those occupied by $H$. panicea. Dredge samples taken from derelict deep-water oyster- and mussel-beds indicated biomass proportions of neighbouring populations of $H$. panicea and $H$. bowerbanki to be on an average about $20: 1$ (localities 8 and 9). Biomass of $H$. panicea is often enormous and certainly higher in this environment than that mentioned for the sluice gate in the previous habitat. Competition between the two species was especially evident on the mollusc beds, where competition with other organisms seemed rather poor. There they frequently overgrew each other and intermingled but could easily be separated. 
The non-tidal environment

With the exception of the localities mentioned below, most brackish inland waters with predominant chlorinities in the polyhaline and mesohaline regimes, do not harbour any sponge populations.

Habitat 5 (localities 11,12,13,14,15 and 16): Mesohaline water (locality 16), polyhaline water (remaining localities); depth 0-7 m; hydrodynamism zero. Available hard substrate and presence of sediment, see habitat 3.

In the brackish canals the two species were found in polyhaline waters only. Populations grow exclusively on silt-free substrates in depths below about $-1 \mathrm{~m}$ beneath mean water level. Niches occupied by them are very similar to those described for the sheltered harbours of the seaside (habitat 3). Population densities and individual sizes were, however, much smaller. This was most pronounced more landinward, where specimens were often minute and difficult to find.

Habitat 6 (locality 17): Polyhaline water; depth $0.5 \mathrm{~m}$; hydrodynamism zero; hard substrate comprises loose-lying stones, twigs and peat clumps, covered with considerable amounts of silt (closed or almost closed layer).

This polyhaline lagoon is the main discrepancy in the sympatric distribution of the species. The small isolated lagoon, quite unique because of its considerable depth and consequently stable environment is only populated by $H$. bowerbanki. The species is restricted here in its upper range to undersides and shaded sides of stones which lack massive algal growth and represented mainly by undersized specimens. In depths beneath $-1.5 \mathrm{~m}$, larger typical specimens covered with silt and debris were commonly encountered on all sides of stones, twigs and peat clumps. The sponge frequently grew here on small reefs of Ectoprocta (Electra crustulenta).

In an attempt to verify whether the marked absence of $H$. panicea in the brackish lagoon (habitat 6 ) is merely a coincidence resulting from the final closure of the creek from the open waters of the Oosterschelde (December, 1953), or whether it can be explained as intolerance of $H$. panicea to the particular environment in the habitat, transplantation experiments were carried out. Six well-grown explants of the species were transplanted to the lagoon, half of them fixed in horizontal position and the other half in vertical position in a frame box and hung on a depth of $-2 \mathrm{~m}$ ( $0.5 \mathrm{~m}$ above the bottom). The vertical situation is not normally encountered in the pool. The site of transplantation was just next to specimens of $H$. bowerbanki growing there naturally. Transplantation took place on March 31, 1978. On June 6, 1978 all horizontal explants appeared to be killed under a layer of silt. The vertical explants were, however, able to counteract siltation rates. Although two explants showed no growth of importance, the other one had grown considerably but remained an incrusting form. On September 1, 1978 only the successful explant was still alive and had grown to develop an appreciable massive base and five characteristic "chimneys". The specimen was left in its position and remarkably enough after the rather harsh winter conditions of 1978-79 it was found in a completely different growth form. It was now composed of a thin, almost incrusting base with many slender branches (PI. II 4). Its external appearance was impossible to tell apart from $H$. bowerbanki in the habitat. Nevertheless, the specimen was later positively identified as $H$. panicea.

We may conclude from the result that with regard to the natural absence of $H$. panicea in the lagoon, its intolerance to sedimentation is the major cause; whether intolerances of larval and juvenile stages may be involved is unknown.

\section{GROWTH FORM - ENVIRONMENT RELATIONSHIPS}

For each species, relationships between growth form and physical conditions in the different habitats are presented in table III.

Colony shape of the sponges seems to be largely influenced by hydrodynamic conditions in the Oosterschelde area. In general, distinct typical forms of the species are mostly represented in low hydrodynamism habitats in the absence of high environmental stress. Exposed to currents of more constant direction the shapes of the species are less typical, bearing most of their outgrowths, 
TABLE III

Relationships between growth forms of Halichondria panicea and $H$. bowerbanki and physical conditions in different habitats (for abbreviations of growth forms, see diagnoses of the species).

\begin{tabular}{|c|c|c|c|c|}
\hline \multicolumn{2}{|c|}{ Environment } & \multirow{2}{*}{$\begin{array}{l}\text { Physical conditions } \\
\text { exposure to air; low to high hydrodynamism; } \\
\text { barren or thin silt film; all slopes }\end{array}$} & \multirow{2}{*}{$\begin{array}{l}\text { Growth forms } \\
\text { H. panicea } \\
\text { P1; P2; P4 }\end{array}$} & \multirow{2}{*}{$\begin{array}{l}\text { Growth forms } \\
\text { H. bowerbanki } \\
\text { B1 }\end{array}$} \\
\hline Littoral & habitat 1 & & & \\
\hline & habitat 2 & $\begin{array}{l}\text { exposure to air; low hydrodynamism; } \\
\text { considerable amounts of silt } \\
\text { a) horizontal, sloping and vertical substrates } \\
\text { b) overhangs }\end{array}$ & $\overline{\mathrm{P} 1} ; \mathrm{P} 2$ & $\begin{array}{l}\text { B1 } \\
\text { B1 }\end{array}$ \\
\hline \multirow[t]{2}{*}{ Sublittoral } & habitat 3 & $\begin{array}{l}\text { low hydrodynamism; much silt; } \\
\text { vertical and overhanging substrates }\end{array}$ & P2; P3 & B2; B3; B4 \\
\hline & habitat 4 & $\begin{array}{l}\text { high hydrodynamism; barren or sand; } \\
\text { all slopes }\end{array}$ & P4; P5 & $\mathrm{B} 2^{*} ; \mathrm{B} 3 * ; \mathrm{B} 4 * ; \mathrm{B} 5$ \\
\hline \multirow[t]{2}{*}{ Non-tidal } & habitat 5 & $\begin{array}{l}\text { low salinity; stagnant; much silt; } \\
\text { vertical and overhanging substrates }\end{array}$ & P1; P2 & B1; B2; B3; B4 \\
\hline & habitat 6 & $\begin{array}{l}\text { low salinity; stagnant; } \\
\text { considerable amounts of silt; all slopes }\end{array}$ & - & $\mathrm{B} 1 ; \mathrm{B} 2 ; \mathrm{B} 3 ; \mathrm{B} 4$ \\
\hline
\end{tabular}

which are often anastomosing, on the downstream side, while under influence of strong alternating current conditions both species may adapt to indistinguishable forms: massive, flattened and without vertical outgrowths.

Furthermore, high stress environments (through siltation, low salinity, exposure to air, limited food) such as intertidal and non-tidal habitats seem to have a major influence on growth forms. High stress ecomorphs remain often undersized or incrusting and hence (particularly in the latter case) make the species difficult to tell apart. The change of growth form of the $H$. panicea transplant in the brackish lagoon as described above is a striking example of this. Furthermore, it is especially noticeable that $H$. bowerbanki is more capable to keep its typical forms in non-tidal habitats.

\section{LIFE CYCLE, GROWTH AND SEASONAL OCCURRENCE} IN THE OOSTERSCHELDE AREA

Both species breed annually and show an almost complete reproductive isolation. During 1978, 1979 and 1980 colonies of $H$. panicea contained reproductive elements from early May through mid August when water temperature increased from about $12^{\circ} \mathrm{C}$ to maximal values of about $19^{\circ} \mathrm{C}$. In the field newly settled colonies were observed as early as 24 May (1979). On the other hand, during the same years colonies of $H$. bowerbanki contained reproductive elements from early August through mid October, when water temperature decreased from maximal values to values of about $14^{\circ} \mathrm{C}$. Newly settled colonies of this species appeared commonly during September, but also in the first half of October (1979).

The species react in a quite different way to winter conditions in the Oosterschelde area. $H$. bowerbanki survives the winter in a dormant form, which is characterized by major disintegration of the tissue and loss of choanocyte chambers (see also Hartman, 1958). The species goes into dormancy as water temperatures are near $4^{\circ} \mathrm{C}$. Marked reduction in population size in $H$. bowerbanki was particularly evident during the severe winter of 1978-79 when the species was drastically minimized in shallow waters (notably in intertidal habitats). During mild winters $H$. bowerbanki seemed able to survive dormancy in the intertidal belt on shaded and protected spots. After such winters repopulation of the exposed intertidal niches seemed to take place during the reproductive period of the species up to early winter after which they were reduced again. $H$. panicea is surviving the winter in the Oosterschelde area in a normal, active state and winter conditions seem 
to have a less adverse affect on its population sizes.

To compare growth rates of the species we measured the zonal outgrowths of explants exposed to optimal habitat conditions (habitat 3), during one period in summer ( 30 June-1 August 1979 ) and during one period in early winter (4 December 1979-7 January 1980). The intention of the experiments was limited and the results have only indicative value. Growth rates of six explants of $H$. panicea suggested for this species a mean length increase of $0.8 \mathrm{~mm} /$ day ( $\mathrm{SD}=$ \pm 0.3 ) during the summer period and of $0.2 \mathrm{~mm} /$ day $(\mathrm{SD}= \pm 0.05$ ) during early winter. Growth rates in $H$. bowerbanki appeared to be higher in the summer period than in $H$. panicea: in four explants $1.1 \mathrm{~mm} /$ day $(\mathrm{SD}= \pm 0.2$ ). On the other hand, six explants of this species showed no trace of growth in the winter period, which agrees with its inactive winter state.

\section{ECOLOGICAL ANALYSIS}

Although the two sympatric species have clearly different life cycles, their niches show generally less differentiation in the Oosterschelde area. Both $H$. panicea and $H$. bowerbanki are euryhaline organisms and both species occupy niches ranging from fully illuminated to totally dark. Likewise, the two species are extremely tolerant to different hydrodynamic regimes, although $H$. panicea seems to prefer higher current conditions. Interspecific competition for space between the species is evident in most of the habitats. Highest population densities and highest interspecific competition are encountered especially in dark sublittoral waters, where competition pressure of other organisms is low.

Niche segregation among the species could be established only in a relative small margin of the Oosterschelde area, namely in parts of the littoral and high siltation habitats (table III). It was found that in the intertidal habitat $H$. panicea occupies a higher range than $H$. bowerbanki; this is in accordance with observations by Burton (1947, English coast) and Graat-Kleeton (1965, West coast of France). This intertidal niche differentiation may be interpreted as a higher tolerance towards desiccation of $H$. panicea. As might appear from the single niches occupied by $H$. bowerbanki, this species is obviously more tolerant towards siltation than $H$. panicea, although also for the former species silt cover may eventually become a critical factor. In general, sedimentation appears to be a prime factor in limiting the distribution of sponges and other sessile animals in the Oosterschelde area. The relatively high tolerance to silt of $H$. bowerbanki may also be apparent by its tendency to have accumulated silt or other debris on its surface, a phenomenon which is rarely seen in $H$. panicea.

Growth forms, regardless of the species, in the Oosterschelde area seem largely phenotypical. Under influence of hydrodynamic forces and in high environmental stress conditions both species adapt to almost similar shapes. According to Jackson (1979) six basic growth forms may be generally recognized among sessile animals reflecting different morphological survival strategies. When we apply Jackson's mostly theoretical considerations to the species examined (disregarding their considerable overlap in growth form), "runner"-like forms (linear or branching incrustations) and "vine"-like forms (linear or branching semi-erect forms with restricted zones or substratum attachment) are mostly found in $H$. bowerbanki. Following Jackson this leads to the assumption that $H$. bowerbanki has a rather fugitive-oriented life strategy. This is in accordance with its somewhat opportunistic distribution pattern. $H$. panicea seems to be able to adopt several widely different forms, most of which can be regarded in Jackson's terminology as "mound"like forms (massive three-dimensional incrustations). As such it is to be considered a highly successful organism (exhibiting to a certain degree a confrontation strategy); distributional data from The Netherlands and elsewhere strongly support this consideration.

An evident role in regulating the life cycles of many invertebrates plays the changing seawater temperature, as suggested by many authors (see for a review Kinne, 1970, and with particular emphasis to sponges, Fell, 1974). In its reaction to water temperatures $H$. panicea exhibits a cooler thermal range for existence and reproduction than 


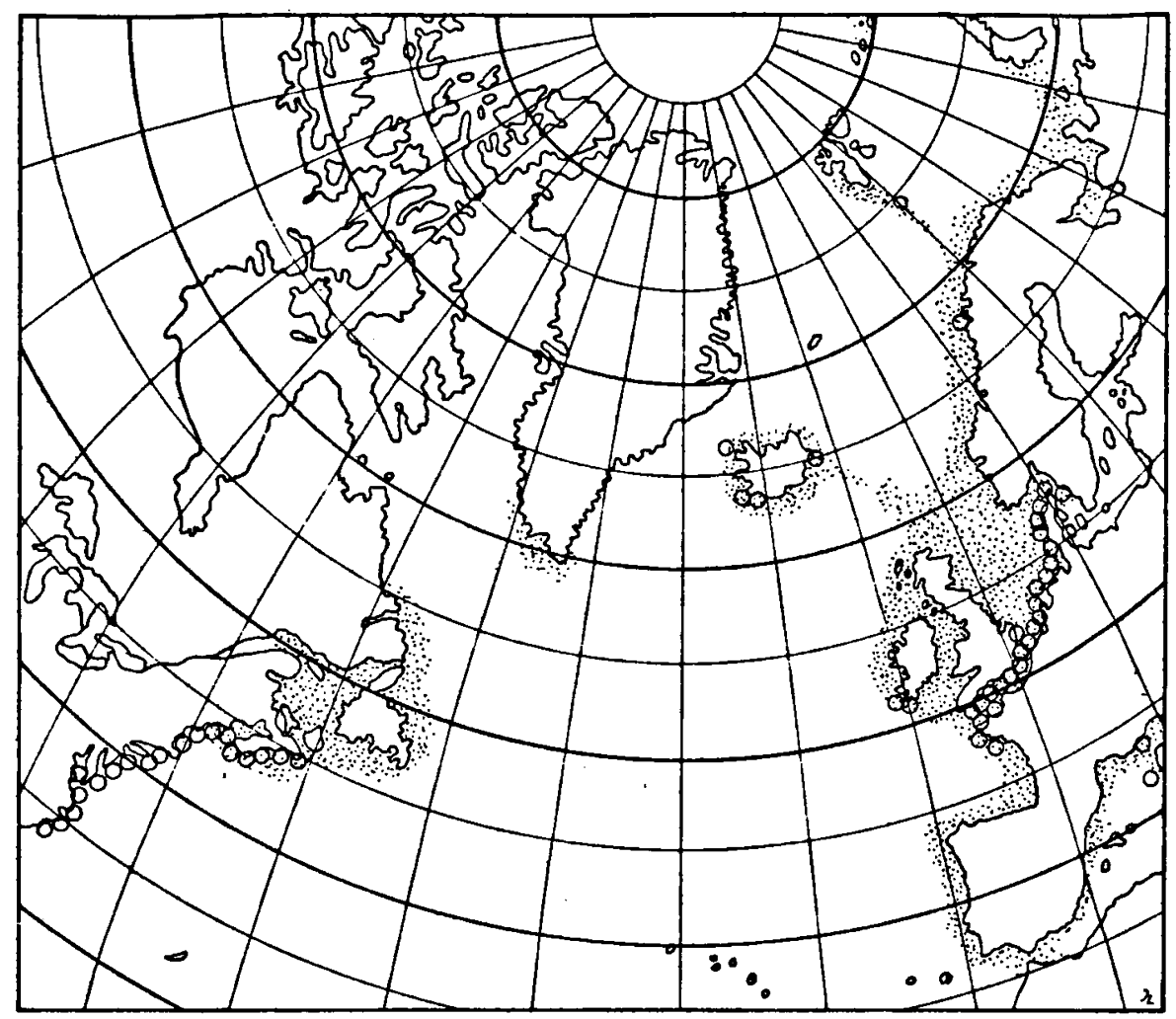

Fig. 4. Distribution (approximated) of Halichondria panicea (dotted areas) and H. bowerbanki (circlets) in the North Atlantic.

$H$. bowerbanki, which requires warmer conditions in the Oosterschelde area.

The reason behind $H$. bowerbanki's opportunistic life strategy, including its faster growth rate, quite likely is the reduced tolerance to lower temperatures, as compared to $H$. panicea. The reduced tolerance causes $H$. bowerbanki to reproduce later in the year and to assume winter dormancy, disadvantages which are apparently not completely compensated by a faster growth rate, at least not in European waters. It cannot be decided whether or not this difference points towards a warm water origin of $H$. bowerbanki.

\section{GEOGRAPHICAL DISTRIBUTION}

When reviewing the literature on Halichondria panicea it soon appears that the species is reported from almost anywhere. Von Lendenfeld (1897), Brøndsted (1924), Vosmaer (1933) and Burton (1959) declared the species to have a cosmopoli- $\tan$ distribution. Halichondria bowerbanki is only reported from the northern Atlantic. The vertical range reported for $H$. panicea is from the intertidal down to $569 \mathrm{~m}$ (Alander, 1942, Swedish coast), for $H$. bowerbanki down to $90 \mathrm{~m}$ (Bowerbank, 1874 , as $H$. coalita, British waters).

When the literature data on Halichondria panicea are critically compared with descriptions of the species from western Europe, it is quite apparent that many of the identifications are wrong. Often spicule size exceeds by far the known range of European specimens, colours are different and odd habits are described. To test this further we have examined a number of specimens from all over the world identified as Halichondria panicea by different authorities, kept in the collections of the British Museum (Natural History) (BMNH), the Zoölogisch Museum of Amsterdam (ZMA), and the Rijksmuseum van Natuurlijke Historie (RMNH) (see list in chapter on materials and methods). 
Definitely not conspecific with $H$. panicea were the specimens from: South Sacchalin (U.S.S.R.), S.W. Patagonia, Falkland Islands, Antarctica, Japan and Sea of Japan, Mergui Archipelago (Birma), Kerguelen, Indian Ocean, Gulf of Aqaba, Pt. Nolloth (S. Africa), and Lambert Bay (S. Africa).

Specimens outside the northern Atlantic which were morphologically very similar to western European $H$. panicea were those from Vancouver (Sheens River, Canada), Atlantide Exped. Sta. $146\left(09^{\circ} 24^{\prime} \mathrm{N} 14^{\circ} 45^{\prime} \mathrm{W}\right)$, and Pt. Chevalier Reef (New Zealand); however, dissimilar specimens from nearly the same areas have also been described and figured (e.g. Kozlov, 1973: fig. 4; Bakus \& Abbott, 1980: 28).

When the data from the specimens studied and the literature are combined, the following picture emerges (fig. 4):

Halichondria panicea predominantly occurs in the northern Atlantic from the Mediterranean and the New England region (e.g. Lambe, 1896) into the low Arctic (southern Greenland, northern Norway, Iceland, northern coasts of the Soviet Union). Conspecific or closely related populations occur in West Africa (Burton, 1956), the northern Pacific (Lambe, 1892, 1893, 1894), and localities in the temperate Southern Ocean, such as New Zealand and southern Australia (e.g. Bergquist, 1970). The species is undoubtedly most common on the Atlantic coasts of western Europe.

Halichondria bowerbanki occurs in the northern Atlantic in roughly the same area as $H$. panicea, but is undoubtedly more common on the western Atlantic coasts (e.g. Hartman, 1958; Wells et al., 1960, 1964; Fell \& Jacob, 1979); really Arctic records are unknown.

\section{GEOGRAPHICAL VARIATION}

Spicule size: In tables IV and V spicule sizes of specimens of $H$. bowerbanki and $H$. panicea from different geographical origin are given. From this it can be concluded that size differences between specimens from northern Atlantic localities and specimens from the northern Pacific, New Zealand and West Africa are unimportant.
Specimens of $H$. bowerbanki from Europe allegedly (Graat-Kleeton, 1965; Hartman, 1958) have larger spicules than those of North America. However, specimens from The Netherlands have spicule sizes quite similar to those from America.

Life cycle: The reproductive periods for both species were determined in France by Topsent (1911); data from The Netherlands given above agree with Topsent's data in general, although breeding periods in The Netherlands are more extensive and some overlap is apparent between the species. Data from N.E. America (Fell, 1974) and New Zealand (Bergquist \& Sinclair, 1973) of $H$. panicea show no marked differences with those of European populations. Hartman's (1958) American $H$. bowerbanki populations apparently differed little from European ones in their reproductive behaviour, but populations studied by Wells et al. (1964) and Fell \& Jacob (1979) showed different reproductive periods. Together with a few other discrepancies this led Fell \& Jacob (1979) to assume American $H$. bowerbanki presents a taxonomic problem.

Summarizing, it appears that there is little or no geographical variation in the reproductive periods: $H$. panicea invariably breeds within a rising temperature range, $H$. bowerbanki in a stable or decreasing temperature range, $H$. spec. Fell \& Jacob in an increasing and decreasing temperature range, higher than that of $H$. panicea.

\section{BIOGEOGRAPHY AND SPECIATION}

According to Briggs (1974) the Atlantic boreal fauna shows a much lower species diversity than the Pacific boreal fauna. The reason he gave for this, is the more severe impact of the climatic deterioration during the Pleistocene glacial periods in the northern Atlantic. The more or less completely wiped out shallow-water fauna allegedly was replenished to some extent by dispersal of the Pacific boreal fauna. Apart from the fact that such an Atlantic-Pacific discrepancy is by no means unequivocally established (cf. for instance Ruddiman \& McIntyre, 1976), this explanation in our opinion covers only part of the problem. The Pacific boreal has its own faunal history, 


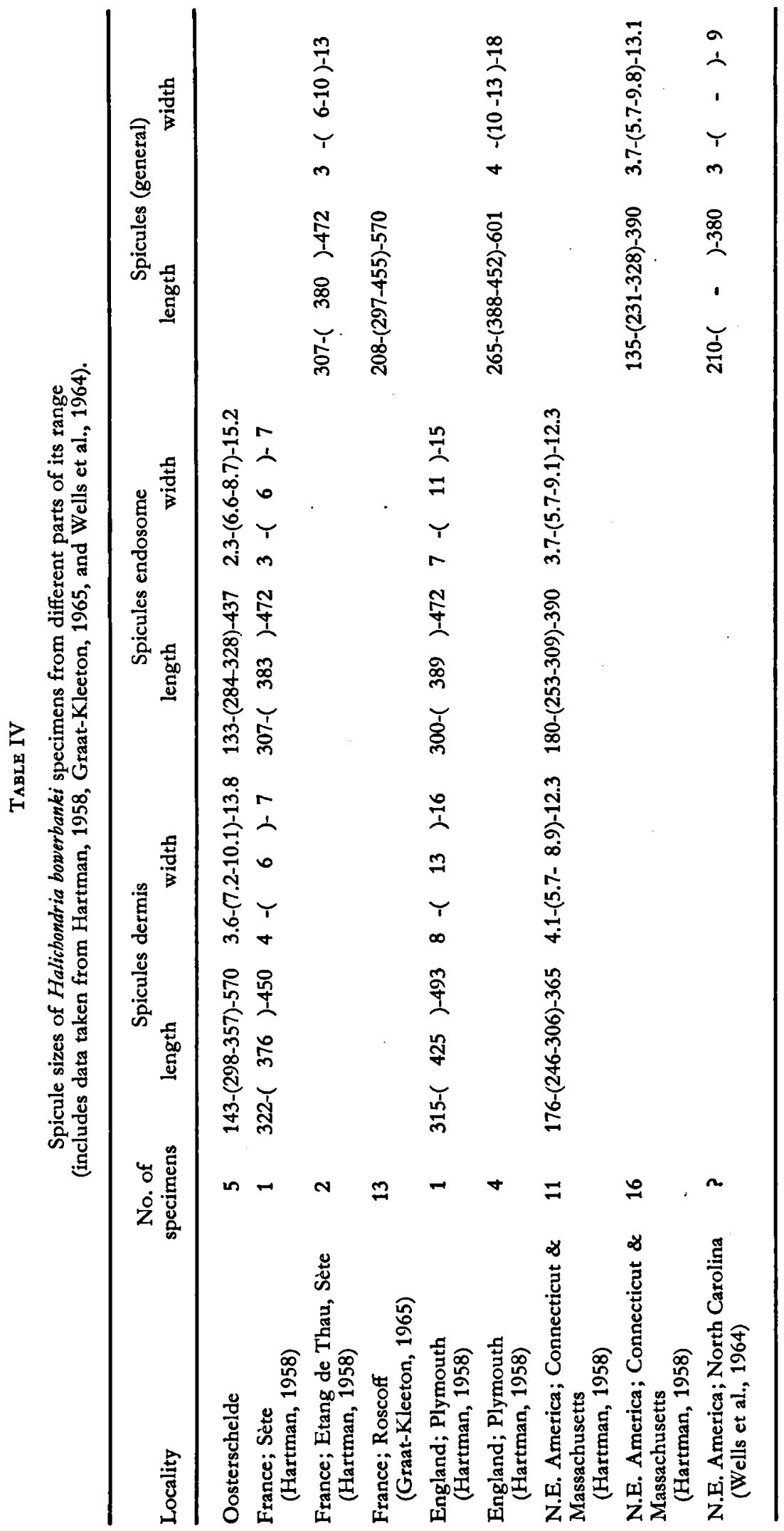


BIJDRAGEN TOT DE DIERKUNDE, 52 (2) - 1982

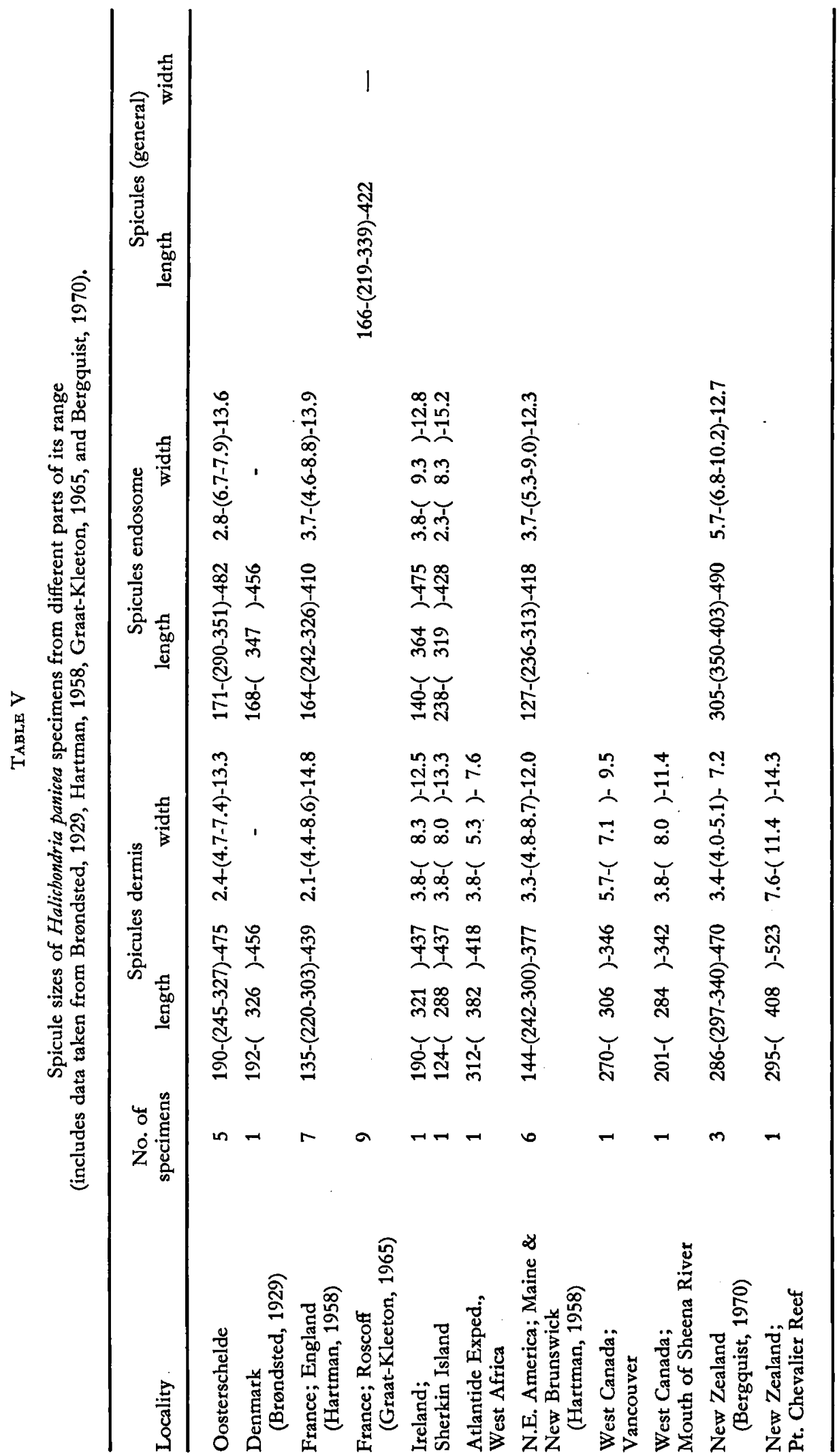


separate from that of the Atlantic. It partly contains faunal elements dispersed from the central Indo West Pacific, the admitted richest shallowwater environment in the world oceans (much richer than its Atlantic counterpart). Also, the Pacific boreal is made up of elements evolved separately on both sides of the Pacific Ocean in geological times, when Asia and North America were much further separated from each other, the latter continent still being attached to northern Europe. Finally, the complicated history of Beringia (Müller, 1974) undoubtedly caused much speciation. Against this long and diverse history, the Atlantic boreal is short-lived and a poorer fauna is the result thereof. Generic elements common to both the Pacific boreal and the Atlantic boreal are probably more easily explained by vicariant events involving past Arctic-boreal distributions, than by one-way dispersal adventures.

From the sections on ecology and geographical distribution it is apparent, that both Halichondria species have their main distribution in the warm temperate/boreal/low Arctic North Atlantic. Within this area $H$. bowerbanki dominates along the North American coast, $H$. panicea along the European coast. This latter observation suggests that $H$. bowerbanki originally evolved in the western Atlantic, while $H$. panicea developed in European waters, both from a parent species that was apparently distributed over part of the whole of the North Atlantic. After the speciation event was completed, invasion of each other's range must have taken place. The isolation of populations of the ancestral species on both sides of the Atlantic may have been effected in two possible ways:

- D i s pers a 1: A parent species, distributed at one side of the Atlantic Ocean, managed to establish "founder" populations on the other side by chance long-distance dispersal of its larvae, during past geological times when a more or less continuous link between northern Europe and northern North America was absent. Reinvasion by the new species of the "home country" would have taken place in more recent times when the situation of the northern Atlantic Ocean was more or less like the present. At the same time, range extension of the parent species into the range of the new species must have taken place. Against this idea pleads, apart from the usual objection to marine long-distance dispersal (for sponges, e.g. Wiedenmayer, 1977), that the northern parts of the continents have been moving away from each other rather than coming closer to each other. - Vicariance: The amphiatlantic range of the parent species was split up by the development of a barrier separating the eastern and western Atlantic populations. Subsequent disappearance of the barrier enabled both new species to invade their respective ranges by the Greenland-IcelandFaroe stepstones. The nature of such a barrier can only have been an extensive lowering of the seawater temperature to high Arctic level $\left(0^{\circ} \mathrm{C}\right.$ or lower). From the distributional data in the literature it would seem, that both $H$. panicea and $H$. bowerbanki apparently do not tolerate extreme Arctic conditions. In addition, a fairly sudden lowering of the sea level could have wiped out most of the predominantly shallow-water populations over a part of the North Atlantic. The fact that such high Arctic conditions have occurred in the North Atlantic in the past 600,000 years indeed, is now well established (cf. Cline \& Hays eds., 1976) in several informative papers on northern Atlantic seawater temperatures, circulation and southward extensions of pack ice. During the Pleistocene period a number of severe glaciations have occurred, which have brought pack ice down to $45^{\circ} \mathrm{N}$, leaving most of the coasts of the Northern Atlantic barren of littoral animals and providing difficult life conditions for shallow

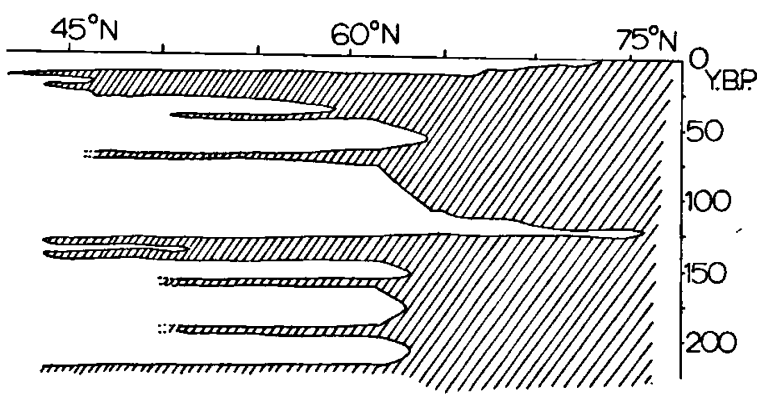

Fig. 5. Extent of polar (hatched area) and subpolartemperate (white area) pelagic flora and fauna in the Norwegian Sea and the northern North Atlantic during the past 225,000 years (based on sediment core analysis). Horizontal axis: latitude north $\left(42.77^{\circ} \mathrm{N}\right)$, vertical axis: years before present $\times 10^{3}$. (Drawn after Kellogg, 1976: fig. 23.) 
sublittoral organisms. It is quite conceivable, that during these climatic deteriorations separation of populations of shallow-water organisms has occurred, although in the case of Halichondria it is not yet clear why not more speciation events have taken place, since there were at least 9 major glaciations. Possibly, invasion of each other's range has only rarely been possible for Halichondria, since climatic amelioration periods (interglacials) of a mildness of the one we live in now, have only happened twice, 125,000 years ago and at present (cf. Kellogg, 1976: fig. 23, here reproduced in fig. 5). A continuous range of a parent species established 125,000 years ago, disrupted about 11,000 years ago, could have resulted in two distinct species, which only recently managed to invade each other's ranges.

This makes it also possible to explain why the Southern Ocean holds populations morphologically similar to $H$. panicea specimens; during the period from 100,000 years B.P. till about $6,000-8,000$ years B.P. (end of Würm glaciation) the Atlantic Ocean was probably cool enough, especially on its eastern side to envisage a continuous NorthSouth Atlantic range of the ancestor of $H$. panicea. To explain occurrence in Australia and New Zealand and several southern Indian Ocean islands, it is necessary, however, to assume a considerable long-distance dispersal. An alternative explanation is to assume recent introduction of the species by man.

\section{REFERENCES}

Alander, H., 1942. Sponges from the Swedish West-coast and adjacent waters: 1-95, pls. 1-16 (Struves, Göteborg).

ANONYMOUS, 1959. Symposium on the classification of brackish waters, Venezia 1958. Archo. Oceanogr. Limnol., 11 (suppl.): 1-248.

—, 1977. Stroomatlas Oosterschelde: [i-ii], 13 unnumbered maps (Dienst der Hydrografie van de Koninklijke Marine, s-Gravenhage).

Bakus, G. J. \& D. P. Аввотt, 1980. Porifera: the sponges. In: R. H. MORRIS, D. P. ABbotT \& E. C. HADDERLEY eds., Intertidal invertebrates of California: 1-690, pls. P1.P200 (Stanford Univ. Press, California).

BERgQuist, P. R., 1970. The marine fauna of New Zealand: Porifera, Demospongiae, part 2 (Axinellida and Halichondrida). N. Z. Dep. scient. ind. Res. Bull., 197 (= N. Z. oceanogr. Inst. Mem., 51): 1-85.

Bergquist, P. R. \& M. E. SINClaIR, 1973. Seasonal variation in settlement and spiculation of sponge larvae. Mar. Biol., 20: 35-44.
Boven, P. J. van, 1981. Chloride gehalte en watertemperatuur van de Oosterschelde bij Yerseke over de periode 1964-1980. Delta Inst. Hydrobiol. Onderz. Yerseke Rapp. Versl., 1981 (7): 1-70.

BowerbaNK, J. S., 1874. A monograph of the British Spongiadae, 3: 3 -367, pls. I-XCII (Ray Society, London).

BRIGGS, J. C., 1974. Marine zoogeography: 1-475 (McGrawHill, New York).

Brinton, E., 1962. The distribution of Pacific euphausiids. Bull. Scripps Instn. Oceanogr., 8: 51-269.

Brøndsted, H. V., 1924. Sponges from New Zealand. Part I. Vidensk. Meddr. dansk naturh. Foren., 77: 435-483. , 1929. Biometrische Studien über Schwämme. I Vidensk. Meddr. dansk naturh. Foren., 88: 1-13.

Burton, M., 1930. Additions to the sponge fauna of Plymouth. J. mar. biol. Ass. U. K., 16 (2): 489-567.

—_ 1947. The identity of Halichondria albescens Johnston and Hymeniacidon albescens Bowerbank. Ann. Mag. nat. Hist., (11) 14: 252-256.

- 1956. The sponges of West Africa. Atlantide Rep., 4: 111-147.

- 1959. Spongia. Zoology Iceland, 2 (3-4): 1-71.

Cline, I. M. \& J. D. HAYs eds., 1976. Investigation of late Quaternary paleoceanography and paleoclimatology. Geol. Soc. America Mem., 145: 1-464.

EkmaN, S., 1953. Zoogeography of the sea: i-xiv, 1-417 (Sidgwick \& Jackson, London).

Fell, P. E., 1974. Porifera. In: A. C. Giese \& J. S. Pearse eds., Reproduction of marine invertebrates, vol. I: 51-132 (Academic Press, New York).

FELL, P. E. \& W. F. JACOB, 1979. Reproduction and development of Halichondria sp. in the Mystic Estuary, Connecticut. Biol. Bull., 156 (1): 62.75.

Graat-Kleeton, G., 1965. Les Halichondria de Roscoff. Proc. K. ned. Akad. Wet., (C) 68 (3): 166-174.

Hartman, W. D., 1958. Natural history of the marine sponges of southern New England. Bull. Peabody Mus. nat. Hist., 12: 1-155.

JACkson, J. B. C., 1979. Morphological strategies of sessile animals. In: C. LARWOOD \& B. R. ROSEN eds., Biology and systematics of colonial organisms. Systematics Association Spec. Vol., 11: 499-553.

KeLLOGG, T. B., 1976. Late Quaternary climatic changes: evidence from deep-sea cores of Norwegian and Greenland seas. In: R. M. Cirne \& J. D. Hays eds., Investigation of late Quaternary paleoceanography and paleoclimatology. Geol. Soc. America Mem., 145: 77-110.

KINNE, O., 1970. Temperature - invertebrates. In: O. KINNE ed., Marine ecology. A comprehensive, integrated treatise on life in oceans and coastal waters. Vol. I. Environmental factors, part I: 407-514 (Wiley Interscience, London).

Kozlov, E. N., 1973. Sea shore life of Puget Sound, the Strait of Georgia, and the San Juan Archipelago: 1-282, pls. I-XXVIII (Univ. Washington Press, Seattle).

LAMBe, L. M., 1892. On some sponges from the Pacific coast of Canada and Behring Sea. Trans. R. Soc. Canada, 10 (IV): 67-78.

- 1893. Sponges from the Pacific coast of Canada. Trans. R. Soc. Canada, 11 (IV): 25-43.

- 1894. Sponges from the western coast of North America. Trans. R. Soc. Canada, 12 (IV): 113-138.

- 1896 . Sponges from the Atlantic coast of Canada. Trans. R. Soc. Canada, (2) 2 (IV): 181-211. 
LENDENFeld, R. von, 1897. On the Spongia of Rockall Island. Trans. R. Ir. Acad., 31: 82-88.

MCGowAN, J. A., 1963. Geographical variation in Limacina helicina in the North Pacific. Syst. Assoc. Publ., 5: 109-128.

MülLER, P., 1974. Aspects of zoogeography: 1-208 (Junk, Den Haag).

MUNCK, W. DE, A. J. J. SANDEe, J. M. VerschuURe \& L. DE WOLFF, 1978. Chloridegehalte, peilvariatie en zuurgraad van een aantal binnenwateren in het Deltagebied gedurende de periode 1968-1975. Delta Inst. Hydrobiol. Onderz. Yerseke Rapp. Versl., 1978 (8): 1.51.

Pierrot-Bults, A. C. \& S. van der Spoel, 1979. Speciation in macrozooplankton. In: S. VAN DER SPOEL \& A. C. PIERRot-Bults eds., Zoogeography and diversity of plankton: 144-167 (Bunge, Utrecht).

Ross, H. H., 1974. Biological systematics: 1-345 (AddisonWesley Publ. Co., Reading, Mass.).

Ruddiman, W. F. \& A. MCINTYRe, 1976. Northeast Atlantic paleoclimatic changes over the past 600,000 years. In: R. M. Cline \& J. D. HAYs eds., Investigation of late Quaternary paleoceanography and paleoclimatology. Geol. Soc. America Mem., 145: 111-146.

SARA, M., 1956. Aspetti genetici ed ecologici dell' ibridazione naturale fra differentie specie di Leucosolenia (Calcispongiae) a Roscoff. Boll. Zool., 23 (2): 1-3.
—, 1957. Problemi di speciazione negli animali marini. Archo. zool. ital., 42 (suppl.): 273-379.

Simpson, T. L., 1963. The biology of the marine sponge Microciona prolifera (Ellis and Solander) 1. A study of cellular function and differentiation. J. exp. Zool., 154: $135-151$.

SOEST, R. W. M. vaN, 1975. Zoogeography and speciation in the Salpidae (Tunicata, Thaliacea). Beaufortia, 23 (307): 181-215.

SOEst, R. W. M. VAN \& S. WeInberg, 1980. A note on the sponges and octocorals from Sherkin Island and Lough Ine, Co. Cork. Ir. Naturalist J., 20: 1-15.

TOPSENT, E., 1911. Sur les affinités des Halichondria et la classification des Halichondrines d'après leurs formes larvales. Archs. Zool. exp. gén., (5) 7: 1-15.

Vosmarr, G. C. J., 1933-1935. The sponges of the Bay of Naples: Porifera incalcarea (ed. by C. S. VosmarrRö̈Ll \& M. BuRToN). Volume II. Capita Zool., 5 (1): $457-875$.

Wells, H. W., M. J. Wells \& J. E. Gray, 1960. Marine sponges of North Carolina. J. Elisha Mitchell scient. Soc., 76: 200-245.

,--1964 . Ecology of sponges in Hatteras Harbour, North Carolina. Ecology, 45: 752-767.

WIEDENMAYER, F., 1977. Shallow-water sponges of the western Bahamas: 1-287, pls. 1-43 (Birkhäuser Verlag, Basel).

\section{LEGENDS TO THE PLATES}

(All photographs by A. D. Vethaak)

\section{Plate I}

Different growth forms of $H$. panicea (for abbreviations, see diagnosis of the species): 1 , growth form P1 on mollusc Mytilus edulis (X 1); 2, growth form P2 (X 1.5); 3 and 4, growth form P4 (X 1); 5, growth form P3 (X 5/4).

\section{Plate II}

Different growth forms of $H$. panicea (for abbreviations, see diagnosis of the species): 1 , growth form P4 (X $5 / 4) ; 2$, growth form P5 $(X 1) ; 3$, growth form P6 $(X 5 / 4) ; 4$, growth form P1, as explant $(X 1)$; growth form P5 on mollusc Crepidula fornicata ( $X 1)$.

\section{Plate III}

Different growth forms of $H$. bowerbanki (for abbreviations, see diagnosis of the species): 1, growth form B1 on mollusc Mytilus edulis (X 1); 2, growth form B2 (X 1); 3, growth form B1 on tunicate Styela clava (X 1); 4, growth form B3* $(X 3 / 4) ; 5$, growth form B 5 on hydroid $(X 1) ; 6$, growth form B2* on mollusc Crepidula fornicata $(X 5 / 4)$.

\section{Plate IV}

1, 2 and 3. Different growth forms of $H$. bowerbanki: 1, growth form B5 $(X 1) ; 2$, growth form B4 $(\times 1)$; 3, growth form B3 $(\times 3 / 4)$. Growth form $H$. panicea from Irish coast $(X 1)$. 


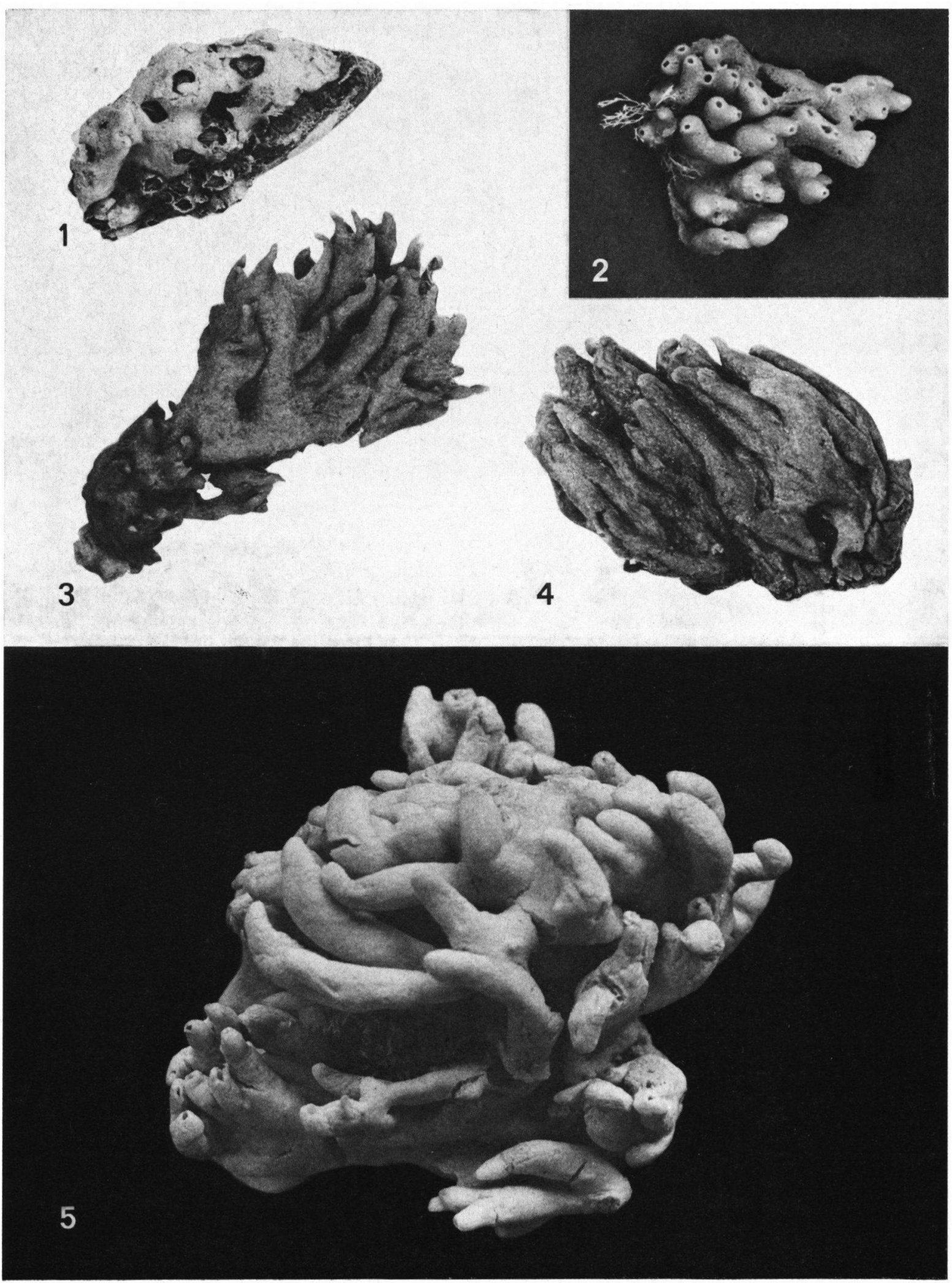

Plate I 


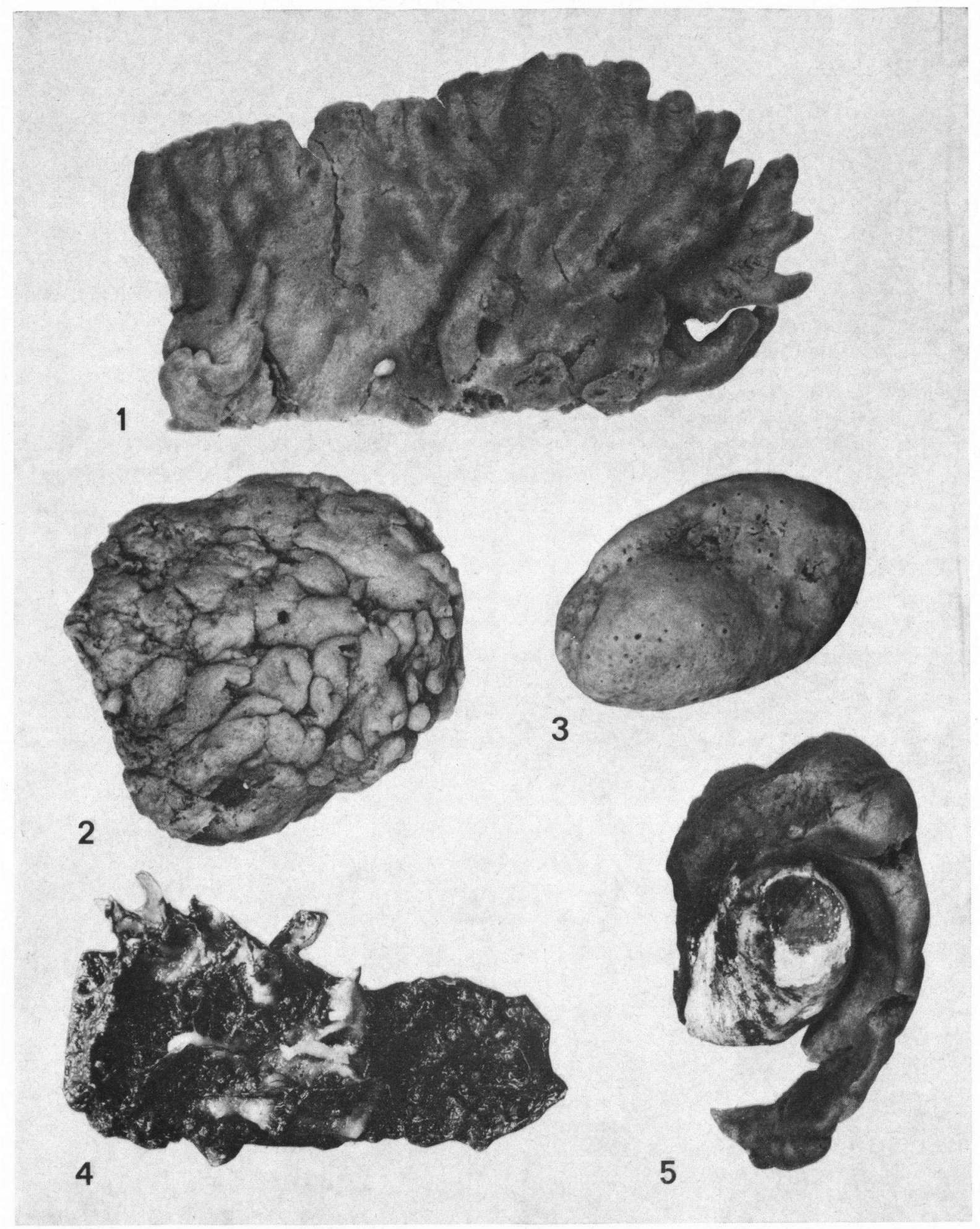

Plate II 

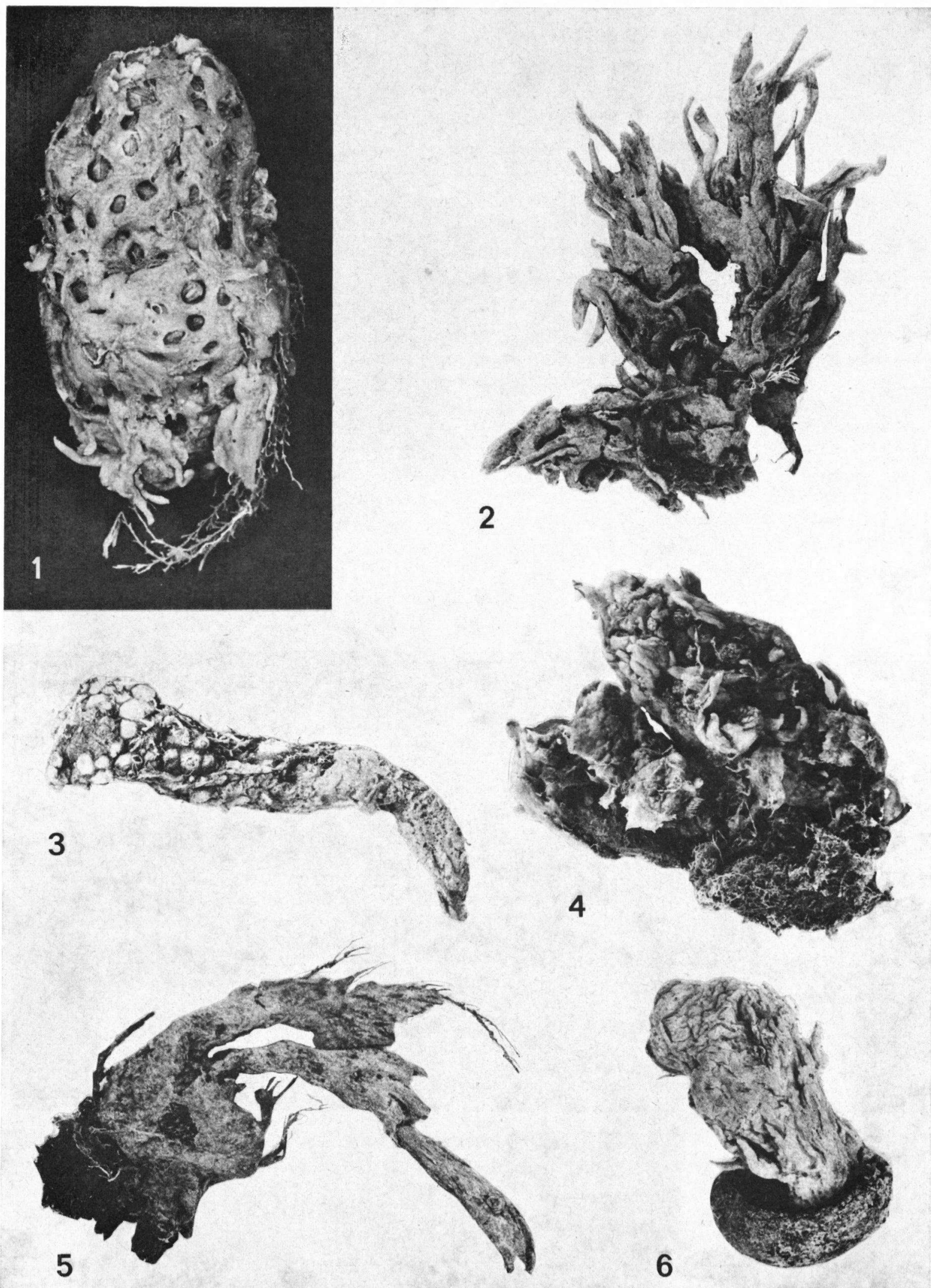

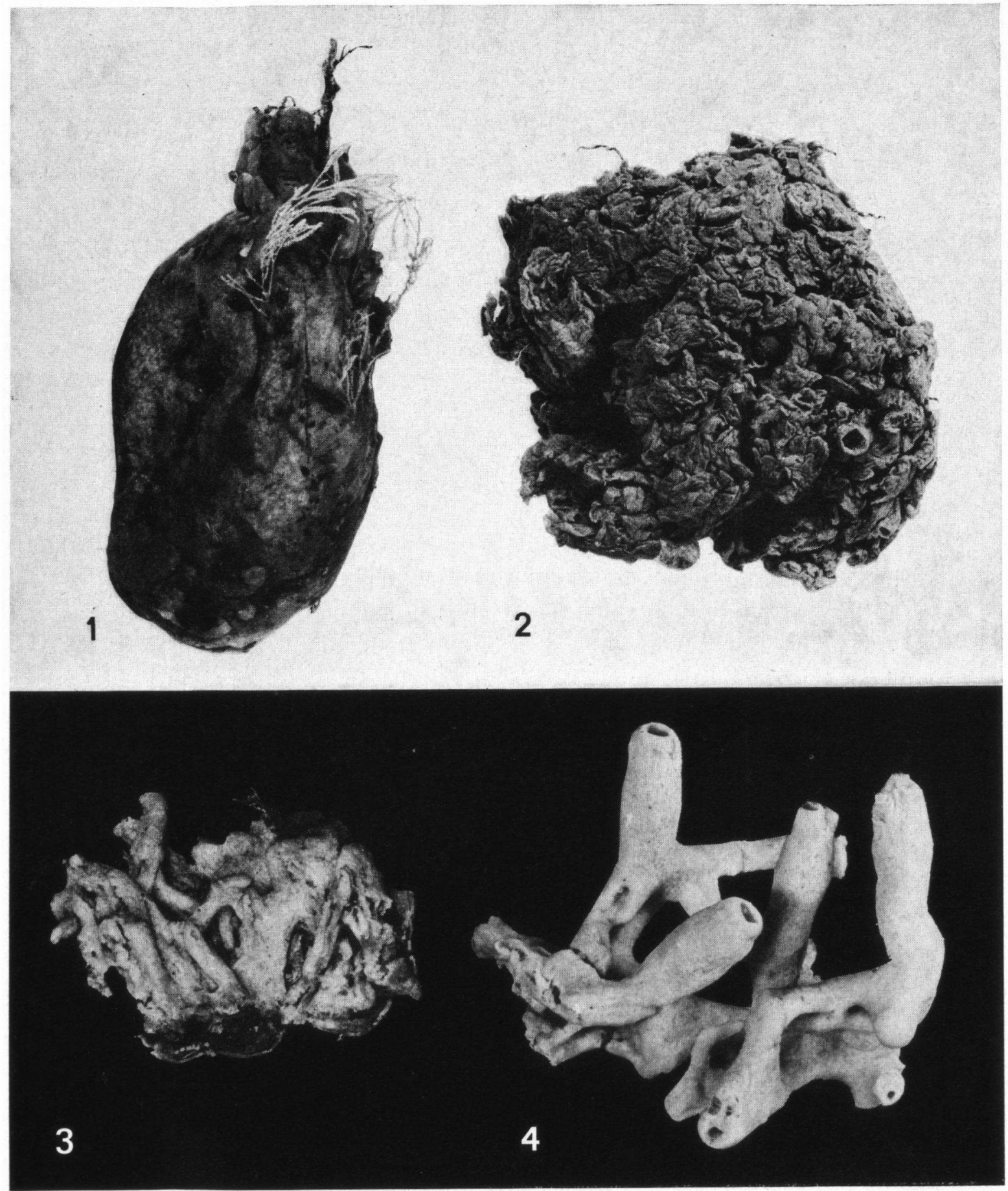

Plate IV 